\section{Martin Luther og reformationen i Danmark}

AfMartin Schwarz Lausten, professor, dr.theol.

$\mathrm{I}$ det følgende vil jeg nævne nogle hovedpunkter fra emnet "Luther og reformationen i Danmark", som illustreres i denne udstilling. ${ }^{1}$ Jeg skal forsøge at undgå gentagelser af det, som jeg sagde i min forelæsning ved kongressens åbning $\mathrm{i}$ universitetets festsal i søndags, men dersom nogle af mine tilhørere alligevel synes, at nu har de næsten hørt for meget om den danske reformation, vil jeg blot minde om et af Philipp Melanchthons vigtige pædagogiske principper: repetitio est mater studiorum!

\section{Den kristne humanisme}

En vigtig forudsætning for den evangeliske - lutherske - reformation i Danmark var den kristne humanisme. Danske studenter, som vendte tilbage fra studieophold ved universiteterne i Paris, Louvain, Wittenberg, Leipzig, Rostock og andre byer tog de nye ideer med sig hjem. Omkring 1700 danske studenter blev immatrikuleret ved europæiske universiteter i årene fra 1451 til 1535. Mest berømt blandt dem blev Christiern Pedersen, som havde taget eksamen i Paris og udgav en række typisk humanistiske lærebøger foruden en del andagtsbøger. En anden var Petrus Parvus Rosefontanus, som i 1519 skrev et forord til bogen Hortulus Synonymorum (1520) af Henrik Smith. Peder fremhævede her vigtigheden studier i det latinske, det græske og det hebraiske sprog, i beskæftigelsen med rhetorik og med antikkens forfattere, og han roste berømte humanister som Erasmus, som han kaldte den larde, anforeren for den litterare har, genstanden for hele kristenhedens beundring. Han nævnte også Petrus Mosellanus og Johann Rhagius Asticampianus, og han omtalte byen Wittenberg som et centrum for humanisme. I denne sammenhæng kaldte han Philipp Melanchthon den allermest larde, og Martin Luther omtalte han som den teologiske doktor, som på fremragende vis søger Guds sandhed.

Dette er første gang, at Luthers navn nævnes i en dansk bog.

\section{Konge Christian d.2.'s humanistiske reformer og overgang til luthersk tro} Det var på denne tid, at det kristne humanisme begyndte at få indflydelse ved Københavns universitet, tilskyndet af Christian d.2., som ønskede at højne universitetets niveau, Han sørgede for, at karmelitterne kunne oprette et kollegium i nærheden af universitetet - i det nuværende St. Pedersstræde - og lederen, Poul Helgesen (ca. 1485-ca. 1535) blev også lektor ved universitetet. Kongen fik også den $\mathrm{i}$ Wittenberg uddannede Martin Reinhard ansat som hofprædikant og Mathias Gabler som lektor i græsk. Fra Wittenberg kom desuden den senere så berømte, i visse kredse berygtede, Andreas Bodenstein von Karlstadt til København. Kongen synes at have haft planer om, at han skulle ansættes som hofprædikant og kgl. rådgiver med særligt ansvar for en ny kirkelig appeldomstol, som han agtede at oprette. Men et eller andet gik galt mellem de to mænd. Karlstadt forlod Danmark efter kun få ugers tid, og ankommet til Wittenberg afviste han at angive grunden til den hastige afrejse fra Danmark, bortset fra at han hævdede, at han havde næret frygt for en bestemt person. Christian d. 
2. var ikke en mand, man skulle rage uklar med.

Kongen lod også udarbejde et større kompleks af reformlove. Erhvervslivet, undervisnings- og kirkevæsenet skulle reformeres, og riget skulle i det hele taget forvandles til en moderne europæisk stat. Gamle skolastiske tekstbøger skulle brændes og erstattes af moderne humanistiske bøger. Eleverne skulle nu læse Terens, Virgil, Cicero, historie, Det gamle Testamente og Det nye Testamente. Men før disse love rigtigt kunne træde i kraft, blev Christian d. 2. fordrevet fra Danmark. I slutningen af 1522 gjorde rigsrådet oprør mod ham. Hans overordnede politik, egensindige styreform og hans ofte særdeles brutale fremfærd fremkaldte opposition fra både de verdslige og gejstlige godsejere. Hans seneste fremfærd i Sverige havde vakt bestyrtelse overalt i Europa. Efter at have slået et oprørsforsøg ned, lovede han fuld amnesti, men brød dette og lod efter en summarisk rettergang henved 80 mænd af den svenske højadel og kirke halshugge på én gang ("Det stockholmske Blodbad"). Også hans skalten og valten med besættelsen af ærkebispeembedet i Lund havde medført fjendskab fra både Rom og det lundensiske domkapitel. Ledsaget af hustruen, Elisabeth - søster til kejser Karl d. 5. - og tre mindreårige børn samt en gruppe loyale medarbejdere ankom han til Nederlandene den 1. maj 1523. Her regnede kongen med at få økonomisk og politisk hjælp af hustruens tante, regentinde Margrethe og den kejserlige familie. Men dette eksil, som kongen vel regnede med skulle vare nogle måneder, kom til at strække sig over godt 8 år, indtil det endelig lykkedes ham at overtale kejser Karl d. 5. til at yde støtte, så Christian d. 2. i spidsen for en hær kunne forsøge en generobring af DanmarkNorge (oktober 1531). Dette forsøg mislykkedes imidlertid, Christian d.2. blev arresteret af efterfølgeren, Frederik d. 1., og han blev holdt indespærret af ham og efterfølgeren Christian d.3. i 27 år, indtil døden befriede ham i 1559 .

Af hensyn til reputationen var kejseren naturligvis forpligtet til at hjælpe familien, rent bortset fra at Elisabeth (Isabella) var hans yndlingssøster. Man havde i sin tid heller ikke udbetalt Christian d. 2. det fulde beløb, da han blev gift med Elisabeth. Der var således grunde nok til, at kejseren skulle yde bistand, og den flygtede danske kongefamilie fik da også overladt en villa i Lier i det nuværende Belgien samt en - ganske vist særdeles beskeden - apanage. Men efter de første måneders forvirring og usikkerhed var kejserens politik her klar: han ville ikke hjælpe Christian d.2. tilbage på tronen. Derimod havde man hemmelige planer om at Christians søn, prins Hans, måske kunne gøres til konge i Danmark. Derved kunne man inddrage det store nordiske rige direkte under den kejserlige interesse. Man opretholdt derfor fra kejserens side formelt det indtryk, at man hjalp kejserens søster og hendes familie.

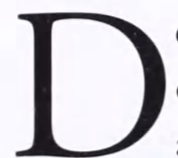
en vigtigste grund til, at kejser Karl d. 5. ikke agtede at hjælpe Christian d.2. direkte var den kendsgerning, at han ganske få måneder efter eksilets begyndelse gik over til den lutherske tro. Allerede i efteråret 1523 lykkedes det ham at få en aftale i stand, så han kunne høre Martin Luther prædike. Det skete i oktober 1523 i landsbyen Schweinitz få kilometer fra Wittenberg. Til stede var også Philipp Melanchthon og den sachsiske kurfyrstes sekretær Georg Spalatin. Fra sidstnævntes dagbogsnotater ved vi, at kongen lige efter Luthers prædiken erklærede, at han aldrig havde hort evangeliet blive forkyndt således. 
Han ville altid bevare det $i$ sit minde, ja han ville hellere lide alt, hvad det skulle vare, end glemme, at Kristus havde lidt korsdoden for uvardige mennesker. Ved denne lejlighed omvendte Christian d.2. sig til den lutherske tro. Det samme gjaldt hans hustru, dronning Elisabeth, samt en række af hans medarbejdere og rådgivere. Det var en bekendelseshandling, men samtidig en politisk dumhed af store dimensioner, totalt afhængig som kongen var af støtte fra kejser Karl d.5., som netop nu stod over for den største skæbnesvangre udfordring i sit liv: det lutherske kætteri. Selvom Luther to år tidligere i Worms af pave, kejser og rigsdag var blevet erklæret kætter og dømt fredløs i kejserriget, bredte kætteriet sig stadig. Den politiske stabilitet var i fare, rent bortset fra, at kætteriet anfægtede hele kejserideologien. Karl d.5. så sig selv som udpeget af Gud til at styre og lede hele den katolske kristenhed, sammen med paven naturligvis. Men hvis denne svigtede, at det gjorde han af og til, måtte kejseren selv handle til Guds ære.

Christian d.2. skulle nu få sin nye evangeliske tro til at passe sammen med sit politiske endemål: generobringen af det danske kongerige. Her havde man valgt Christian d.2.'s farbroder, den holstenske hertug Frederik til ny konge (Frederik d.1.), $\mathrm{og} \mathrm{i}$ håndfæstningen, som rigsrådet præsenterede ham for, gjorde rigsrådet det umisforståeligt klart, at man agtede at opretholde den romersk-katolske tro i kongeriget Danmark-Norge. Bemærkelsesværdigt er det, at Luthers navn er gledet ind i dette danske politiske dokument, idet den nye konge skulle sværge på, at Vi aldrig vil tillade nogen katter, Luthers discipel eller andre at predike og lare, lonligt eller äbenbart imod den himmelske Gud, den helligste kirkes tro, den helligste fader paven eller Romerkirken. Men hvor de findes udi vort rige, ville vi og skulle lade dem straffe ved deres liv og gods. Som evangelisk (luthersk) blev Christian d.2. således en endnu større politisk fare for det danske rigsråd og den nyvalgte konge, end han havde været tidligere.

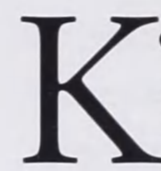
ort efter sin lutherske omvendelse rejste Christian d.2. til Wittenberg. Med bolig i den berømte maler Lucas Cranach den Ældres store ejendom opholdt kongen sig her i nogle uger. Siden - bl.a. i årene 1524, 1526 og 1527 - boede han i flere omgange igen i Wittenberg Kongen førte samtaler med Luther, som på forskellig måde hjalp ham, og der opstod straks et meget fortroligt forhold mellem dem. Lige fra begyndelsen var Luther uhyre optaget af kongen og hans skæbne, og når de ikke personligt mødtes, opretholdt de kontakt med hinanden, enten direkte eller via den kurfyrstelige sekretær Georg Spalatin. Kontakten med Luther og andre berømtheder i Wittenberg bevarede kongen også via danskeren Poul Pedersen Kempe. Han havde undervist i Torgau, var glødende lutheraner, heftig og lidenskabelig i sin sprogbrug og antikatolske polemiske stil, og han havde åbenbart en vis fri adgang til Luther selv. Ved en bestemt lejlighed kunne Kempe således i et brev til kongen trøste denne med ordene: Om Luther skal I $i$ sandhed vide, at han elsker Eder i et og alt... Vi har også bevaret prædikener, som Luther holdt, medens kongen var til stede i kirken. Det er interessant at bemærke, at Luther her kommer ind på mange af de helt centrale emner i sin nye kristendomsforståelse og forskellen mellem denne og den romerskkatolske tro. Ligeledes betoner han den evangeliske bekendelses nødvendighed, og hans ord om Kristus som den store trøster i al nød må have virket som balsam på kongens forpinte sjæl. 
STren tere wentres laser off betende wor rEylo es mod guo hano hafiuc fo loffuio of wio fin 420

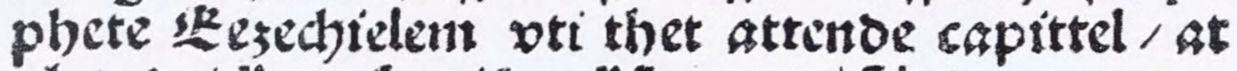

bano icte wat vribugtóme wor fono our $/$ mos font mij mifbaffue thentom, (1) lader of

bese bannom om bans made/thi bano baffuer loffuio off at huas wat bes gere aff banno vri Cbrifti mafme meo en reat PEictelig troo/ thet

reulle mä mofongge Joban nis oti tbet fextende corpit tel/mí wiol idte buos long tijoen ex/the tres gen ere falt frams gongne fom r ful lo ronme (effres Cbrift ouro ) for Domateongen tberforlaoer off woge vtighos ouro/ nedebanoenoe limper/ at nax Cbzifus moz baus goul Eommer/entigen om aff" tenen, eller oc on minonattis tádoc/oc banctier parat wí motrs ware tede oc lad hannom ing/os fo ingange meo bannon, vti thit suige wernfEab/butlet bereo er alle bans os toloe belgen/thet onde of alle gub fower/ fyits oc tbeno bellig and/ Jifu Chaifit nade oc mills Euno ware mes eoer alle 2 nnen. Gereffuit ote 2 ntozop vti 25 zabanot aax effer Chzifti fyojoft todende femburdacoe partbat fire of tyuge ant. 
Den første direkte følge af kongens nye tro var hans initiativ til at få Det nye Testamente oversat til dansk. På moderne vis nedsatte han en lille bibelkommission, bestående af de mænd, som han havde med sig hjemmefra og enkelte andre, som hver fik en part at oversætte. I det væsentlige arbejdede man på grundlag af Luthers tyske Nye Testamente, og allerede i foråret 1524 forelå bogen færdigtrykt. Det var første gang, at Det nye Testamente blev udgivet på dansk i sin helhed, og den skulle nu sendes ind i Danmark, hemmeligt. Alle Luthers fortaler og indledninger tog man med, ligesom bogen også blev forsynet med et billede af Christian d.2. som konge, udført af Lucas Cranach. Udarbejdelsen af værket var i sig selv en bekendelseshandling og et kirkepolitisk dokument. Karakteristisk nok tydeliggjorde man dette derved, at Hans Mikkelsen - tidligere borgmester og handelsmand i Malmø og kongens mest fortrolige hjælper og rådgiver i eksilet indsatte et særligt "opråb" til det danske folk, anbragt mellem Apostlenes Gerninger og Romerbrevet. Han henvendte sig både til danske kvinder og mænd, og han rettede her en række alvorlige anklager mod de danske katolske biskopper, som indtil nu havde bedraget hele befolkningen. De havde fordrejet Bibelens sande mening, ikke ladet evangeliet forkynde, de stod bag en række antikristne pavelige buller, og de havde således holdt hele folket i et babylonisk fangenskab. Hans Mikkelsen brugte naturligvis bevidst dette udtryk, som Luther havde anvendt $i$ et af sine alvorligste polemiske skrifter imod den romersk-katolske kirke. Men nu var det blevet muligt for den danske befolkning at antage den sande kristne tro, for nu var deres rette konge, Hans Mikkelsen og andre loyale mænd gået over til den evangeliske tro. Folket skulle med andre ord sørge for, at Christian d.2. atter blev konge i Danmark, og han henviste her til de skriftsteder, som Luther altid anvendte, når han understregede undersåtternes lydighedspligt over for verdslig øvrighed (Rom. kap. 13 og 1. Peters brev kap. 3). Men tiden var ved at løbe ud, erklærede Hans Mikkelsen, og den sidste side i denne henvendelse havde han - som det ses i det her fremlagte eksemplar - snildt udformet som et timeglas, hvor Kristi navn var placeret i centrum.

I Danmark reagerede man ved erklære rigets faste loyalitet over for paven, love at forfølge eventuelle lutheranere i landet og ved at lade Poul Helgesen tage sig af Hans Mikkelsen. Det gjorde han med skriftet Till thet ketterlige wcristelige och wbesindige Breff, som then wbesckemmede Kettere Hans Michelsen aff Malmo lod wdgaa met thet ny Testamente, ther Konningh Cristiern lod ynckellige och witlborlige forwandle paa sith tijranniscke Wildt, og icke Gudt till Loff, Eet kort och tilborligt Swar. Trods den sidstnævnte bemærkning fyldte bogen 117 sider. Poul Helgesen gennemheglede Hans Mikkelsens ringe sproglige evner, han kunne hverken latin, tysk eller dansk, mente han, og dette svarede nøje til Hans Mikkelsens person, hans slette egenskaber og karakterbrist. Poul Helgesens mageløst talentfulde evner som skarpsindig polemiker udfolder sig her på en særdeles underholdende måde, med teologisk og historisk indsigt, vid, satire og humor. Skriftet er vigtig til belysning af Poul Helgesens egen specielle dogmehistoriske placering inden for katolicismen og hans syn på lutherdommen, uanset at han ofte slår over i perfide personlige angreb mod Hans Mikkelsen.

Andre følger af Christian d.2.'s overgang til lutherdommen var nye henven- 
delser til den danske befolkning, som han hemmeligt lod sende ind i riget. Desuden udvirkede han, at hans søster Elisabeth, gift med kurfyrste Joachim d.1. af Brandenburg, også gik over til den lutherske tro. Dette medførte en politisk skandale af stort omfang i Europa. Kurfyrsten var en af de mest brændende katolske fyrster i riget. Han havde siddet i den kommission, som forhørte Luther i Worms i sin tid, han havde været den første til at indføre stærkt antilutherske love i sit fyrstendømme, og nu tilsluttede hans egen hustru sig kætteriet.... Ikke nok med det: en aften, da Joachim deltog i et jagtselskab i Berlin, flygtede hustruen og ankom til det lutherske Kursachsen. Bag planen stod broderen Christian d.2., som også personligt var i aktivitet, da kareten overskred grænsen til Kursachsen. Materiale i Christian d.2.'s arkiv viser, at han også stod bag sagens skrivelser og dokumenter. Elisabeth vendte aldrig tilbage til manden.

\section{Andre følger af kongens}

lutherske tro var, at han optog hemmelig kontakt med illegale evangeliske kredse i Nederlandene, indkøbte luthersk litteratur, hvilket også var forbudt i Nederlandene, og blandt de ansatte ved det lille eksilhof bredte den lutherske tro sig. Inkvisitionen lod en overgang Hans Mikkelsen, hoffoureren Wilhelm von Zwolle og et par andre mænd arrestere, og det endte med at hoffoureren som kætter blev brændt levende på bålet i Mecheln (1529).

Christian d.2.'s eksil blev i det hele taget en lang kæde af tragedier og personlige sorger og ulykker. Et hårdt slag for ham var det, da hans hustru afgik ved døden (1526) efter et ganske kort sygeleje. De to var i eksilet blev knyttet tæt til hinanden - bevarede breve giver et godt indtryk af dette - og Christian d.2. skrev sønderknust til Luther lige efter dødsfaldet. Han fortalte om de sidste timer og kunne oplyse, at hun heldigvis døde i den evangeliske tro efter at have modtaget nadveren på denne sande måde. Da man et par hundrede år senere åbnede sarkofagen fandt man i en blyæske en skrivelse af en af de katolske gejstlige, som havde været til stede ved dødslejet. Han kunne oplyse, at dronning Elisabeth døde i den romersk-katolske tro efter at have fået den sidste olie og modtaget nadveren på katolsk vis...

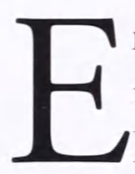
n stærk markering af Christian d.2.'s tilknytning til Luther var også Luthers omtale af kongens skæbne i skriftet Ob Kriegsleute auch im seligen Stande sein können (1526), i hvilket Luther alvorligt bebrejdede danskerne, at de havde fordrevet deres af Gud indsatte øverste verdslige øvrighed. Uanset at kongen måske nok havde begået visse uretfærdige handlinger, burde rigsrådet have overladt straffen for dette til Gud selv. De havde derimod grebet ind i Guds herredømme og havde dermed bedrevet gudsbespottelse og kunne være sikre på Guds hævn og straf.

Luther holdt fast ved Christian d.2., også efter det mislykkede generobringsforsøg. At Christian d.2. i den sammenhæng havde bildt kejseren ind, at han fortrød sit lutherske kætteri, kendte Luther vist nok intet til. Han skrev et endnu bevaret trøstebrev til den fængslede konge på Sønderborg slot. Samtidig bad han den danske konge Frederik d. 1. om at vise barmhjertighed over for fangen. Så vidt vi ved, værdigede Frederik d. 1. ikke Luther et svar. Originalbrevet fra Luther til Frederik d.1. (28/9 1532) findes her i Det Kgl. Bibliotek. I de følgende år vendte Luther af og til tilbage til Christian d.2.'s skæbne. Har nogen nogensinde hort noget lignende? udbrød 


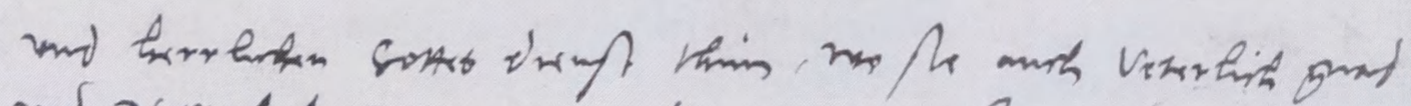

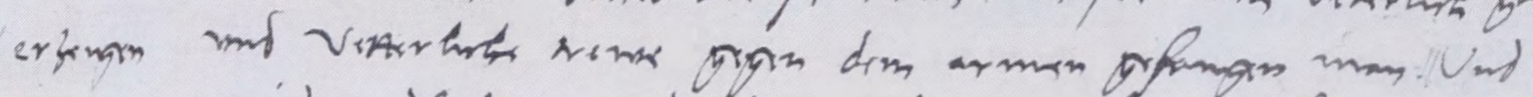

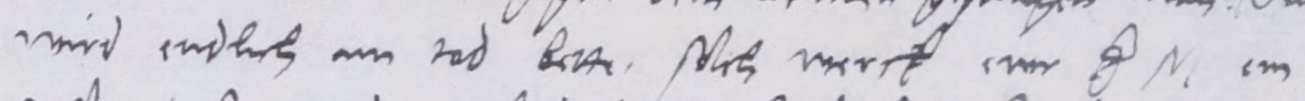

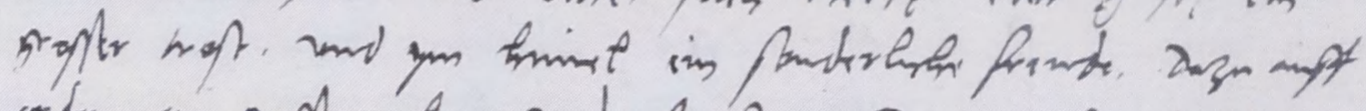

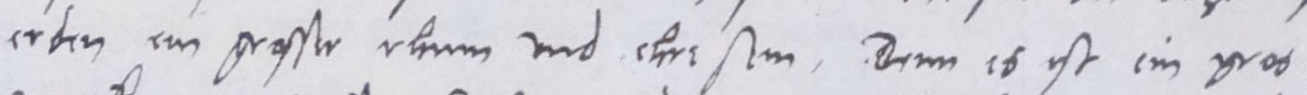

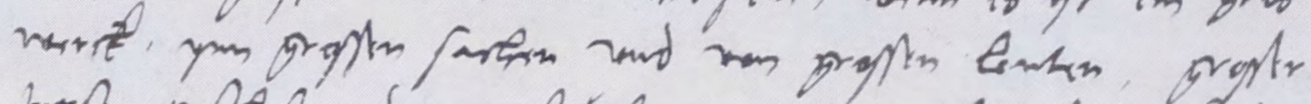

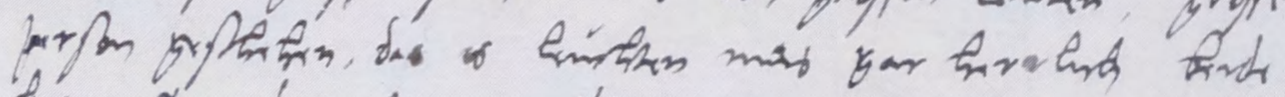

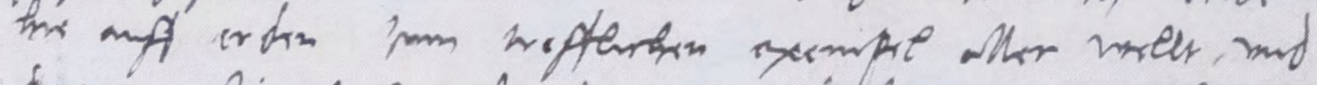

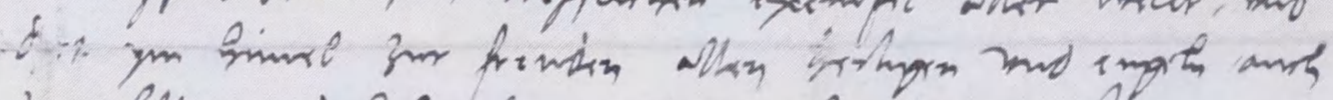

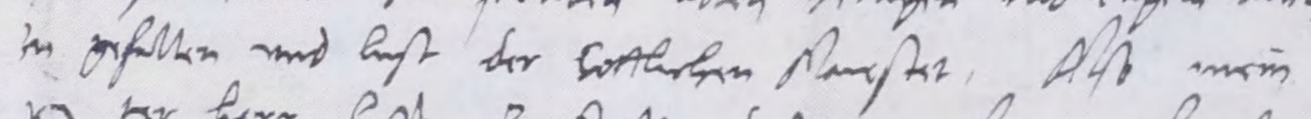

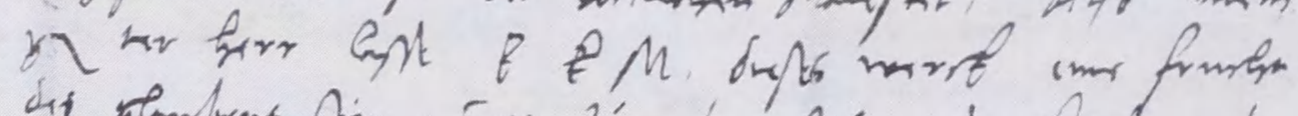

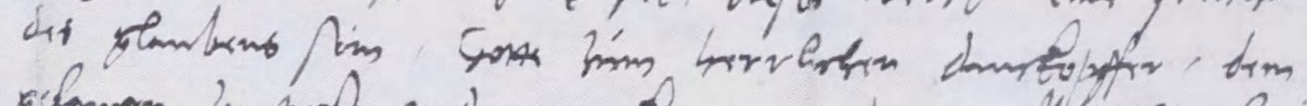

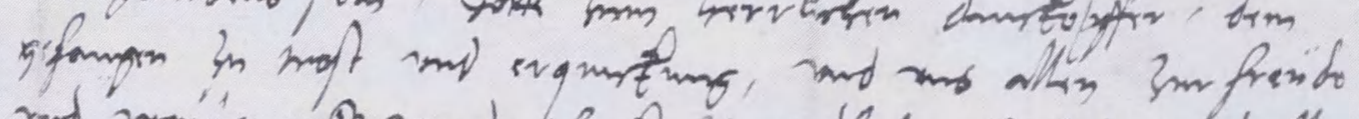

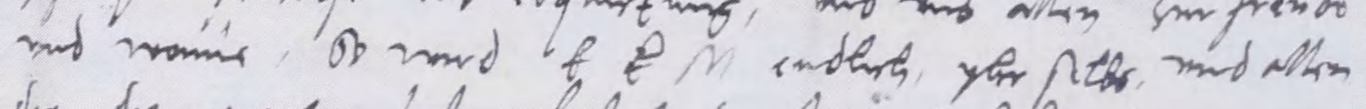

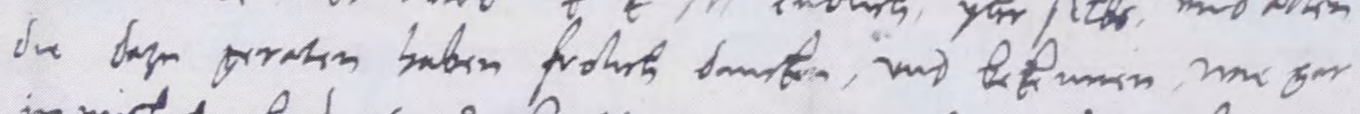

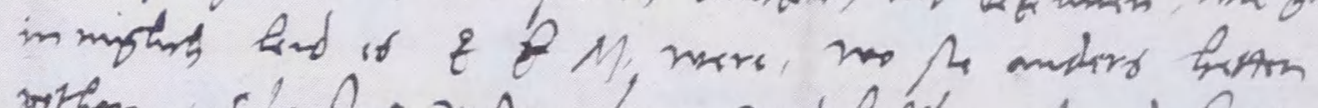

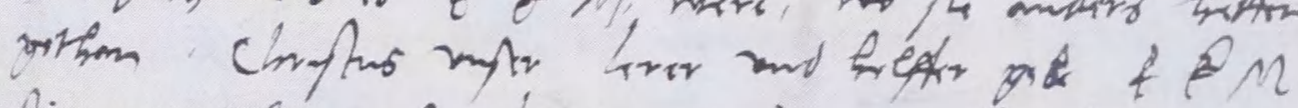

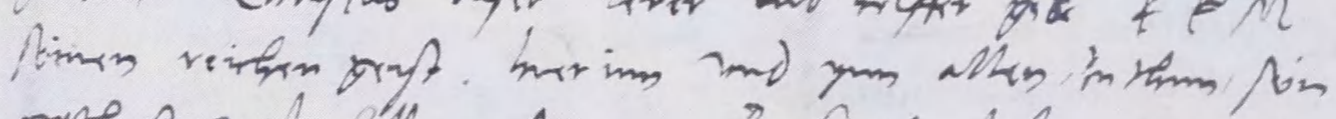

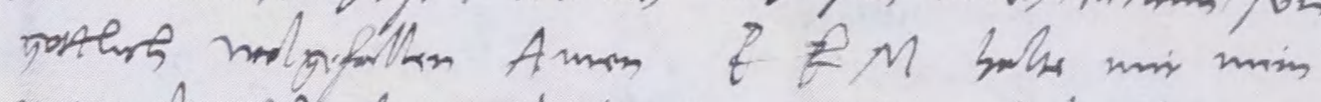

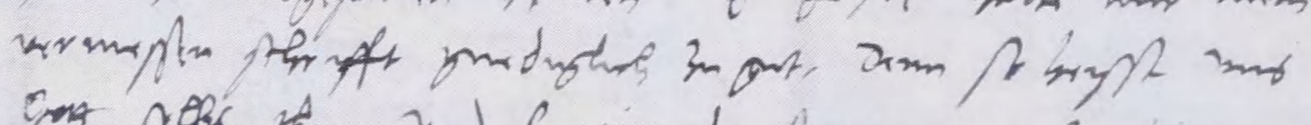

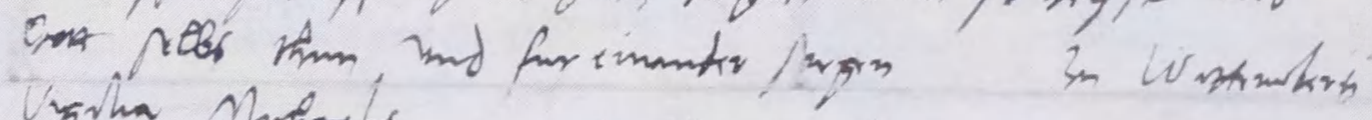

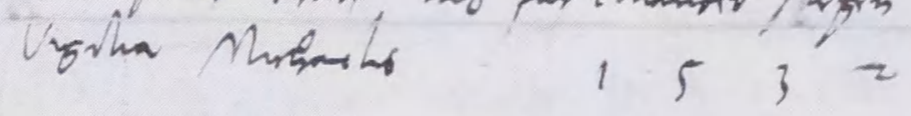

\section{f $\&$ 作}

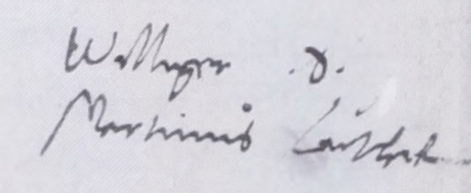

Afslutningen på Martin Luthers brev til kong Frederik d. 1., i hvilket han beder kongen vise barmhjertighed mod den fangslede kong Christian d. 2. på Sonderborg Slot. (Wittenberg d. 28. sept. 1532). Det Kgl. Bibliotek, Ny Kgl Saml 2339. (Foto: Det Kongelige Bibliotek). 
han en gang i en af de kendte Bordtaler, da han talte om den berømte og berygtede nordiske konge, som blev evangelisk og endte i livslangt fangenskab.

\section{Hertug Christians lutherske reformation i Haderslev}

Reformationen i kongeriget Danmark var tæt forbundet med udviklingen i hertugdømmerne Slesvig og Holsten. Hertug Christian, den senere konge Christian d.3. af Danmark-Norge, var som ung blevet undervist af den evangeliske Wolfgang von Utenhof, uddannet i Wittenberg, og da hertugen en tid opholdt sig hos sin onkel kurfyrste Joachim d.1. af Brandenburg, rejste han med dennes delegation til rigsdagen $\mathrm{i}$ Worms i foråret 1521 og oplevede her forhøret og domfældelsen af Luther. Christian blev glødende lutheraner, og han gennemtvang rask væk den lutherske reformation i det lille område omkring Haderslev, som han fik overdraget som len. Omkring 60 sogne hørte ind under ham, og ved hjælp af to lutherske teologer fra Tyskland, Eberhard Weidensee og Johann Wenth, oprettede han den første lutherske fyrstekirke i Norden (1526).

Tiggermunkene blev fordrevet, hertugen overtog den kirkelige administration, et evangelisk præsteseminarium blev etableret, hvor de katolske præster skulle omskoles til lutherdom. På en synode i 1528 fik de udleveret de såkaldte Haderslevartikler, som indeholdt forskrifter for den nye lære og ceremonier. Det var den første evangeliske kirkeordning i Norden, og dens tilknytning til den wittenbergske lutherdom er tydelig nok. Skriftet blev først fundet i det 19. århundrede og vises her. Man læser her bl.a., at den unge hertug var så brændende i sin lutherske tro, at han direkte forlangte, at samtlige præster nu skulle gifte sig. Han stillede det ikke frit, som Luther, men krævede, at de præster, som ikke ville gifte sig, over for ham skulle angive deres grunde! De vanskeligheder, som Luther havde med de af ham benævnte svermere slap man heller ikke for her. Nogle af de fremlagte småbøger beretter om det heftige opgør, som hertugens teologer havde med sværmeren Melchior Hoffmann, som huserede i området sidst $\mathrm{i}$ $1520^{\prime}$ erne. Han blev fordrevet efter en offentlig diskussion i Flensborg, som hertug Christian personligt overværede.

Det romersk-katolske establishment, de gejstlige og de verdslige godsejere, må have været dybt bekymrede over, at kongens søn kunne stå i spidsen for en sådan udvikling så at sige på dørtærskelen til Danmark, uden at kongen greb ind.

\section{Den folkelige evangeliske bevægelse i kongeriget fra omkring 1525}

Trods de løfter, som Frederik d.1. havde afgivet ved sin tiltrædelse i 1523 , bredte den evangeliske bevægelse sig hastigt i Danmark fra midten af 1520 ' erne, og dette skyldtes ikke mindst den sociale og økonomiske krise, som det danske samfund befandt sig i på denne tid. Til dette kom så den religiøse uro. Enhver, som fulgte med, kunne uden videre forestille sig, hvad der ville ske, dersom reformationsbevægelsen ville nå landet. Dette skete ikke desto mindre, og to herredage i Odense 1526 og 1527 betegnede et vendepunkt. Konge og rigsråd blev bl.a. enige om, at man ved fremtidige bispeudnævnelser ikke længere skulle indhente bekræftelse, konfirmation, hos paven, men hos den danske ærkebiskop, og de betydelige beløb, som man hidtil i den anledning havde betalt til paven, skulle for fremtiden udredes til kongen. Desuden ser det ud til, at kirken i Danmark nu deltes i to, nemlig den officielle romersk-katolske, styret 
som hidtil af biskopperne, og den evangeliske således, at de evangeliske åbenbart selv kunne oprette menigheder der, hvor de havde mulighed for det. I de følgende 10 år udspilledes én lang åndelig kamp mellem disse to parter. I udstillingen vises en lang række af de bevarede polemiske skrifter.

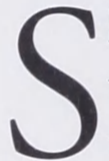
kæbnesvangert for den katolske part var det, at ingen af biskopperne var teologer af uddannelse. På nær en enkelt var de alle adelsmænd. Den eneste forsvarer for katolicismen af nogen betydning var karmelitterlederen Poul Helgesen, men han var ikke en traditionel katolik, for han lå på linje med den reformkatolicisme, den kristne humanisme, som Erasmus af Rotterdam havde udviklet. Dvs. han kritiserede mange forhold i den katolske kirkes lære og fromhedsliv, tog afstand fra alt for megen dyrkelse af skolastikken, fordi den lagde mere vægt på de middelalderlige kommentatorer og teologer end på Skriften. I stedet for ønskede han, at man studerede Det nye Testamente, Kristus, Peter og Paulus, som han sagde, ligesom han også stærkt betonede nødvendigheden af studier af de klassiske sprog. Han kunne enes med Luther om nogle reformkrav, mente også som denne, at mennesket blev frelst af troen alene, men han understregede samtidig nødvendigheden af sand fromhed. Gode gerninger var, ret forstået, også nødvendige, og Poul Helgesen havde ingen planer om at forlade den katolske kirke, selvom han nok så stærkt kunne kritisere både de danske katolske biskopper og dele af fromhdeslivet. Idealet for en sand kristen var for ham en forening af teologisk lardom og fromt liv. På den anden side stod de evangeliske predikanter. Den mest fremtrædende var Hans Tausen, tidligere johannitter. Studierejser havde bl.a. ført ham til Wittenberg, hvor han blev glødende lutheraner. Men opgøret mellem Poul Helgesen og disse første evangeliske reformatorer blev særdeles personligt og bittert. En af grundene var, at flere af dem havde været hans studenter og som karmelitter boet sammen med ham i St. Pedersstræde. Hos ham havde de lært bibelkritik og forstået, at det først og fremmest drejede sig om studiet af Det nye Testamente, de havde hørt ham kritisere dele af det katolske fromhedsliv og kræve reformer. Men de var gået et skridt videre og blevet evangeliske, lutherske, og de forstod ikke, at deres mester ikke fulgte dem. I sin Skibbykronike - som her for en sjælden gangs skyld vises offentligt - omtaler han dem som kætterske, onde, snu, fordrukne, løgnagtige og skamløse, og hans kritik af deres ord og handlinger regner skånselsløst ned over dem side efter side. Værst blandt dem var i hans øjne Hans Tausen. Da han slog sig ned i Viborg (1526), kunne Poul Helgesen meddele, begyndte lutheriets gift at snige sig op gennem Jylland.

Den reformatoriske bevægelse var, ligesom i Tyskland, en typisk købstadsbevægelse, og i begyndelsen af 1530'erne var alle de større byer gået over til den. I Østdanmark blev Malmø midtpunktet (1527), og få år senere tilsluttede København sig også.

Når man gennemlæser skrifterne af disse reformatorer, kan man ikke undgå at bemærke, at der for dem var en nøje sammenhæng mellem deres evangeliske teologi og deres sociale harme, deres kar up mod de velhavende katolske gejstlige personer og institutioner, og deres kamp for nyordningen af samfundet vedrørende fattigforsorg og undervisning. Med bid, humor og satire hudflettede de modstanderne, de katolske prælater og stillede de enfoldige sande kristne op over for dem: 


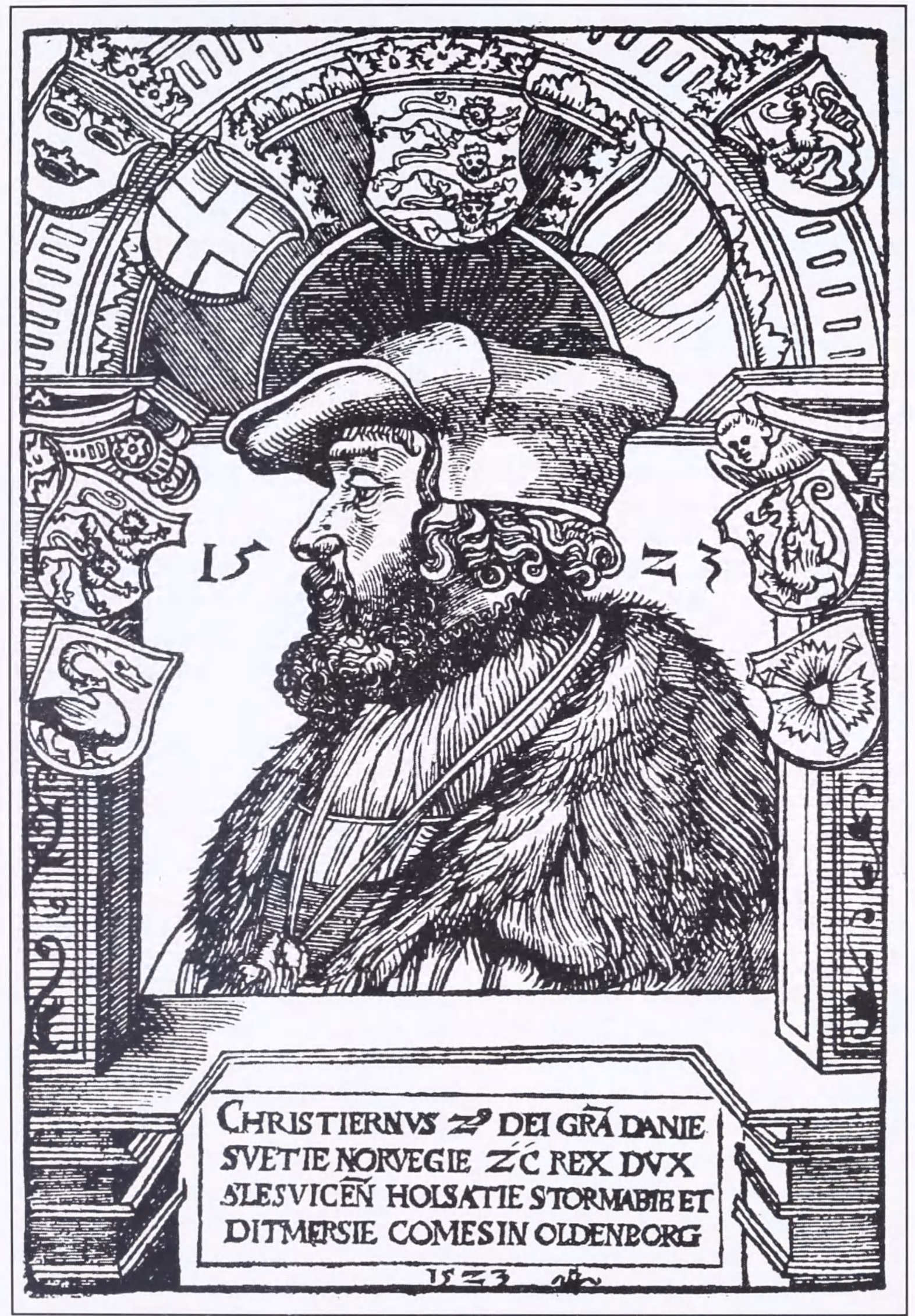

Tresnit af Chr. d.2. udfort af Lukas Cranach d. Eldre, Wittenberg efteraret 1523. Bagsiden af titelbladet til de fire evangelier $i$ Chr. d. 2.'s Ny Testamente (1524). (Foto: Det Kongelige Bibliotek). 
En fattig mand, dreng eller pige, som sidder på en mogvogn og synger de 10 Guds budord eller en anden lovsang af Skriften, Gud til lov og pris, er bedre anset hos Gud end mange praster, munke eller kanniker, som stär fra morgen til aften, knurrende og räbende uden ret kristen tro og gudelighed, intet agtendes hvad de siger, synger eller leser...

Poul Helgesen var rystet. Han mente, at kvinders sang i kirkerne med klingende stemme bevirkede, at manges hjerter og sind bevages mere til syndige tanker end til nogen gudelighed.

I nyere forskning har man debatteret disse første danske reformatorers teologiske standpunkt, og det er blevet hævdet, at de på de afgørende punkter ikke havde forstået Luthers teologi rigtigt, eller at de måske bevidst afveg fra ham. De skulle derimod snarere høre hjemme i den evangeliske bibelhumanistiske bevægelse, sådan som man kendte den i Syd- og Nordtyskland. Det synes i hovedsagen at være rigtigt, men det skal dog straks tilføjes, at de mente om sig selv, at de var gode lutheranere. Som sådan blev de også opfattet og benævnt af deres hovedmodstander Poul Helgesen.

\section{Den kongelige reformation i Danmark- Norge 1536/37}

Efter konge Frederik d.1.'s død (1533) ville det katolske flertal i rigsrådet, først og fremmest biskopperne, skrue udviklingen tilbage. De ophævede de givne indrømmelser til de evangeliske, indledte en kætterproces mod hans Tausen, og de agtede tilsyneladende selv at styre riget indtil videre, idet de undlod at vælge en ny konge. Men de tabte udviklingen af hænde, udenlandske magter blandede sig, og borgerkrigen Grevens fejde - brød ud. Imod rigsrådet og de adelige godsejere stod borgerne og bønderne, som kæmpede for at genindsætte den fængslede Christian d.2. på tronen.

Den anden side så sig til sidst tvunget til at forhandle med den lutherske hertug Christian fra Haderslev for evt. at tilbyde ham tronen. Da han garanterede adelen de gamle privilegier, svigtede de biskopperne, og da han blev spurgt om holdningen til det religiøse spørgsmål efter en sejr, gav han det dunkle, men sigende svar, at det ville han til den tid ordne på en god kristelig måde. Den 6. august 1536 kunne han-Christian d. 3 . - ride ind i København som borgerkrigens sejrherre. Han havde nu adskillige problemer: retsopgørets problem, skylden for borgerkrigen skulle placeres, det økonomiske problem, lejetropperne skulle betales, det religiøse problem, den lutherske tro skulle være den eneste tilladte i riget. Alt dette fik han løst på én gang ved at arrestere samtlige katolske biskopper og gøre dem eneansvarlige for alle ulykkerne. Da de var fjernet, eksisterede den katolske kirke ikke længere, hele bispegodset blev "nationaliseret”, og vejen lå åben for gennemførelsen af den lutherske reformation. Resten af det gamle rigsråd måtte gennem forpligtelsesbreve finde sig i denne fremgangsmåde.

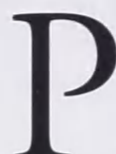
å et møde på Gammeltorv den 30.oktober 1536 markeredes den dybtgående ændring i stat og kirke. Helt efter Luthers anvisninger blev den verdslige og åndelige øvrighed adskilt, biskopperne røg ud af rigsrådet. Danmark skulle for fremtiden regeres rent verdsligt. Den katolske kirke og tro ophørte, for fremtiden var kun den evangeliske (lutherske) tilladt. Nye lutherske biskopper - som dog til at begynde med fik den i Tyskland anvendte titel superintendent-blev udpeget, og kongen nedsatte på helt moderne vis en kommission, som skulle udarbejde et forslag 
til en slags grundlov for de kirkelige forhold, en kirkeordinans. Ingen steder var reformationen blevet gennemført på så dramatisk vis, og Christian d.3. følte det nødvendigt at orientere selveste Martin Luther for at spørge, om dette var i orden. I sit brev (2.december 1536), som vi viser her, gav Luther kongen sin fulde støtte: Det gleder mig, at Deres kgl. Majestet har fjernet (ausgerottet) biskopperne, som jo ikke ville holde op med at forfolge Guds Ord og bringe forvirring i det verdslige styre, og jeg vil til enhver tid forsvare dette... I sin iver efter at gøre det hele korrrekt forsøgte kongen også at fa enten Luther selv, eller Philipp Melanchthon eller Johann Bugenhagen til at rejse til København for at hjælpe med kirkens reorganisering.

Men Luther havde andet at tage sig til, Melanchthon var ikke meget for en tur til det fjerne Danmark. En astrolog havde en gang advaret ham mod at rejse over et stort hav, så det blev Bugenhagen. Et bedre valg kunne man næppe have truffet. Han, som både var den ledende gejstlige i Wittenberg og forelæser ved universitetet, var en habil teolog, fremragende administrator, kirkeretskyndig og havde allerede udarbejdet evangeliske kirkeordninger for områder i Tyskland, som var gået over til den lutherske tro. Kongen havde i øvrigt truffet ham i sin tid i Flensborg, da man gjorde op med sværmeren Melchior Hoffmann, og det viste sig snart, at "kemien passede" perfekt mellem kongen og ham. De kunne udveksle en slags morsomheder i breve, Bugenhagen havde et vist frisprog over for majestæten og kunne endda finde på at bebrejde ham, når han var utilfreds med kirkepolitiske tiltag.

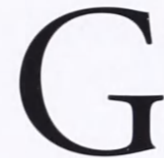
ennem fire store højtideligheder i august/september i 1537 markerede man nu bruddet med den romersk-katolske kirke og gennemførelsen af den evangelisk-lutherske reformation:

1) Kongeparret blev kronet og salvet ved en højtidelighed i Vor Frue kirke, København. Det foregik på kongens fødselsdag den 12.august, men sagen var ikke uden komplikationer. I katolsk tid blev denne for statsstyret helt afgørende handling ledet af ærkebiskoppen, hvis salving af kongen var uomgængelig. Undervejs i det katolske ceremoniel fremstilledes kongen som en slags halvgejstlig, han iklædtes en diakondragt og måtte nyde både vin og brød i nadveren, hvilket ellers kun var tilladt gejstlige. Men kunne man inden for lutherske rammer foretage en sådan kroning og salving? Var det ikke netop en sammenblanding af det verdslige og det åndelige? Det mente man åbenbart i København, at man kunne. Man anvendte tilmed det gamle katolske ritual, men "kristeliggjorde" det, dvs. man fjernede de led, som i særlig grad ledte tankerne hen på den romersk-katolske kirke og tro.

Bugenhagen blev ordinator, og hele det bevarede ritual med hans talrige handlinger, taler og forklaringer er et særdeles interessant aktstykke. Et af højdepunkterne var det øjeblik, da den kronede og salvede Christian d.3. med sværdet i den ene hånd oplæste dagens evangelium. Det var næppe Luthers adskillelse af den verdslige og det åndelige øvrighed, som tilskuerne havde i tankerne den dag i Vor Frue kirke.

2) Bugenhagen indviede de 7 nye lutherske biskopper (superintendenter) 
ved en højtidelighed i Vor Frue kirke.

Bugenhagen var ikke selv bispeviet med håndspålæggelse efter den gamle tradition, så de danske biskopper mistede ved denne lejlighed den såkaldte apostolske efterfolgelse, hvis man holder sig til den katolske forståelse af dette begreb.

3) Christian d.3. underskrev den nu udarbejdede Kirkeordinans, som vises her. I det indledende kongebrev berettede han om arbejdets gang, fremhævede, at loven var blevet godkendt af den arvardige fader doktor Martin Luther, ved hvem Gud afsin mildhed og barmhjertighed $i$ disse sidste tider igen har sendt os Kristi hellige og rene evangelium. Han nævnte også, at rigsrådet havde billiget indholdet, ganske vist efter at der var foretaget nogle ændringer, og han understregede sin egen pligt og sin ret til at genskabe en sand kristendom og kirke i riget. Endelig var kongebrevet fyldt med heftige polemiske udfald mod den romersk-katolske kirke.

4) Københavns universitet blev genåbnet. Det "gamle" universitet, oprettet i 1479, var som overalt en katolske institution, underlagt biskoppens tilsyn. Nu blev det et luthersk, kongestyret universitet med et vist selvstyre. Det mistede dog ikke den kirkelige karakter, konfessionen blev blot udskiftet også her. Det kan ikke overraske, at de nye statutter og bestemmelser for de enkelte fakulteter blev udformet efter forholdene ved universitetet i Wittenberg, dvs. det var Melanchthons og Luthers overordnede synspunkter på et universitets formå og indretning, som blev gældende også her i København. Den her fremlagte

\author{
Ordinatio lectionum in Academia \\ Hafniensi giver et lille indblik i \\ niveauet. Bugenhagen stod ligeledes \\ her i spidsen for reorganisationen. \\ Vigtigst blandt de højere fakulteter \\ blev selvsagt det teologiske, som blev \\ udstyret med flest professorer (tre). De \\ fik også de højeste lønninger. Det \\ gælder desværre ikke længere! En af \\ dem blev Sjællands biskop, som nu \\ skulle forsøge at varetage dette kræ- \\ vende dobbeltembede, en understreg- \\ ning af den nære kontakt, som man \\ ønskede, mellem universitet og kirke.
}

\section{Luthers og Wittenbergs indflydelse på den danske reformations kirke}

Skulle der have været lidt usikkerhed om de tidlige danske reformatorers teologiske position, så var denne $\mathrm{i}$ hvert fald ganske fjernet nu. Christian d.3. var urokkeligt indstillet på, at den danske kirkes teologiske grundlag var den lutherdom, som var udformet i Wittenberg. Luther og Melanchthon udgjorde i fællesskab den læremæssige autoritet, og kongen ignorerede, at de med tiden fik hver deres teologiske særpræg. Wittenberg blev Danmarks åndelige centrum. I de 30 år fra 1530 til 1559 rejste henved 250 danske studenter til Wittenberg, mange af dem med kongens understøttelse, og kongen jagtede uophørligt lærde mænd i Wittenberg, som kunne ansættes i Danmark som biskopper, hofprædikanter eller professorer, for - som han en gang skrev til professorerne ved Wittenberg universitet, I ved jo, hvad slags mand, vi har her i Danmark! Wittenbergs store indflydelse viste sig også i gudstjenesteordningen og anvisningerne for de øvrige kirkelige handlinger, i salmerne, i de mange kateketiske skrifter og andre litterære hjælpemidler til præsterne, som vi her har 
vist et lille udvalg af. Betydningsfuld blev bl.a. Hans Tausens Postille, inspireret naturligvis af Luthers Kirchenpostille. Periodens litterære hovedværk var Christian d.3. 's Danske Bibel (1550), som karakteristisk nok byggede på Lutherbibelen fra 1545. Det første salmehefte udkom i Malmø allerede i 1528, men er desværre ikke bevaret. Det efterfulgtes af en række andre, og højdepunkter blev her Hans Thomissøns salmebog (1569), som var i funktion næsten helt til begyndelsen af det 18. århundrede.

Peder Palladius blev den første lutherske biskop over Sjællands stift. Han fik bolig der, hvor Københavns biskop nu bor, skråt over for Vor Frue kirke. Han var kongens rådgiver i teologiske spørgsmål og samvittighedssager og bindeleddet mellem regeringen (kongen) og kirkens øvrige biskopper og præster. Hans 6 års studier i Wittenberg hos Luther, Melanchthon, Bugenhagen, Jonas og andre afsluttedes med den sjældne teologiske doktorgrad. Her forsvarede han teser, som var skrevet af Luther, og som drejede sig om det helt centrale dogmatiske tema forholdet mellem troen og gerningerne. Palladius var en udmærket teolog og navnlig en fremragende organisator og administrator, en dygtig pædagog og strålende folkelig forfatter. Hans mere end 50 skrifter viser tydeligt Luthers og Melanchthons teologiske indflydelse og $\mathrm{i}$ særlig grad sidstnævntes metode. Andre kendte biskopper blev Peders broder Niels, som i 1550'erne bestred Lunds stift, Jorgen Jensen Sadolin i Fyns stift og Hans Tausen, som blev biskop i Ribe. Alle har efterladt sig en række teologiske skrifter, håndbøger, salmer, polemiske bøger mod katolicisme, drukkenskab, banden og udfordrende moderigtige klædedragter og meget andet.
I sin Visitatsbog, hvis ældste manuskript (17.årh.) fremvises her, beskriver Peder Palladius, hvorledes han holder visitatser i sit stift. Wittenbergteologerne var sidst i $1520^{\prime}$ erne begyndt at foretage disse rejser rundt i Kursachsen for både at få et indtryk af det åndelige niveau, at undersøge sognenes økonomiske forhold - på begge områder oplevede de store skuffelser - og for at fortælle om den nye evangeliske tro. Palladius' bog er formentlig skrevet som en håndbog for kollegerne, og den viser, hvorledes han forteller den sjællandske bondebefolkning om alt det nye. Uden et eneste fremmedord eller teologiske begreber gennemgår han den lutherske kristendom, Ordets forkyndelse, dåbens og nadverens betydning osv. Han polemiserer mod katolicismen, bruger billeder og lignelser. Han lokker og truer menighederne til at gå flittigt i kirke, holde kirke og kirkegård i god stand, betale præst og degn det nødvendige, sende dygtige børn i skole, undlade den gamle Ave-Maria-bøn, glemme alt om dyrkelse af jomfru Maria og andre helgener, give almisser til de fattige. Han advarer mod svir og hor ved Majfesten, formaner bønderkarlene til forsigtighed, når de møder løsagtige kvinder i købstaden. Men biskoppen viser også forståelse for bondens trælsomme slid, og han giver gerne lov til at holde festlige sammenkomster hjemme i landsbyerne, hvor man tilmed kan drikke sig lidt over tørsten, i al høviskhed naturligvis, og for alt i verden skal man lade være med at synge gamle katolske helgenviser ved sådanne fester! Alt krydres med vittigheder, underholdende vendinger, barske eller rørende oplevelser fra andre egne af Sjælland. Biskoppens besøg i landsbykirken har været en uforglemmelig oplevelse. 


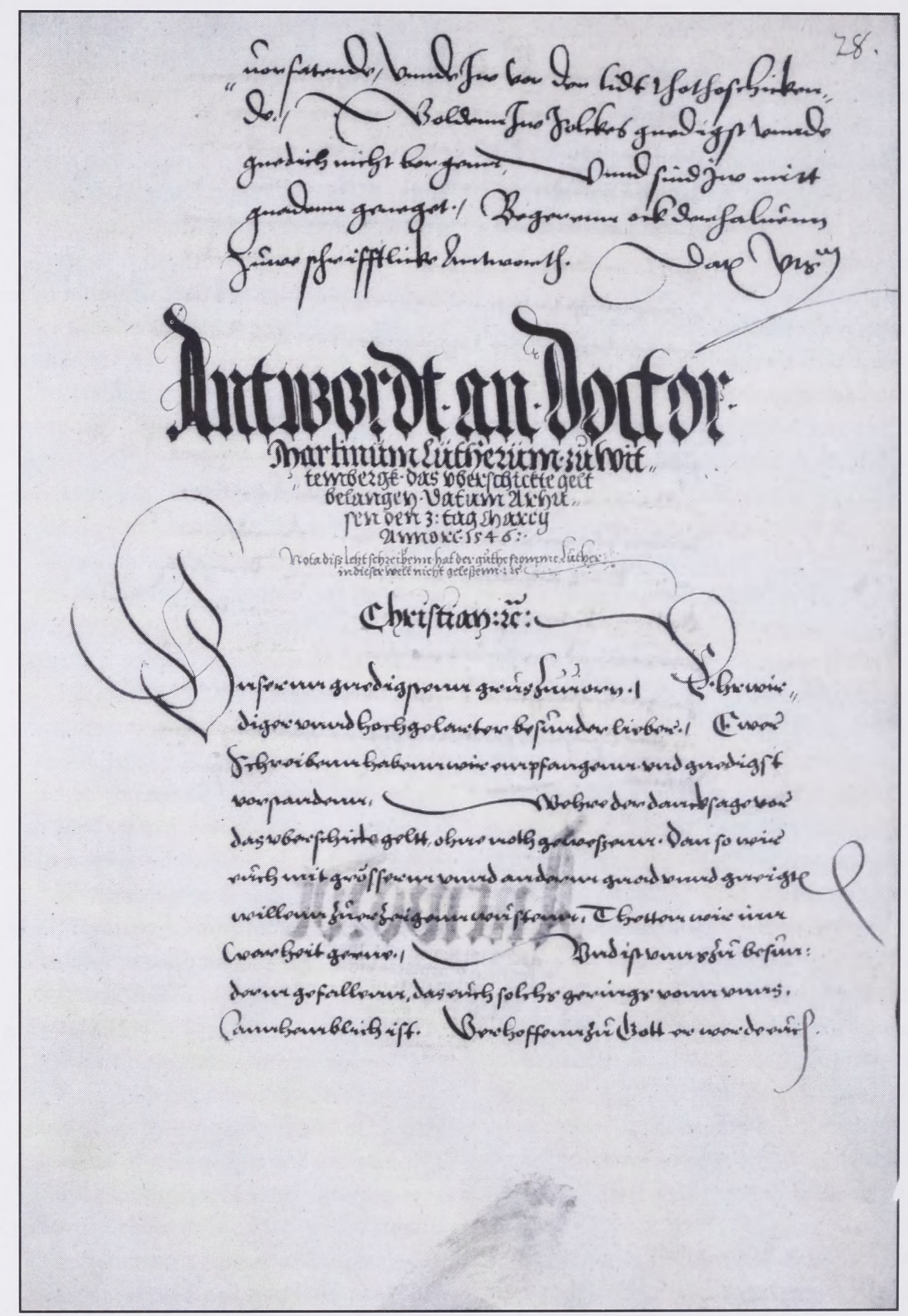

Indledningen til Chr. d. 3.'s sidste brev til Martin Luther, indfort i kancelliets kopibog (3. marts 1546), Rigsarkivet. (Foto: Det Kongelige Bibliotek). 
$\mathrm{E}$ $\mathrm{n}$ af de andre biskopper, Oluf Chrysostomus fra det nordligste stift i Jylland, har også efterladt sig et særdeles spændende vidnesbyrd fra sine visitatser i $1550^{\prime}$ erne. Det er ikke en visitatsbog, men derimod en lang bogliste. Han noterede simpelthen titlerne på de bøger, som hver enkelt præst havde stående i sin bogreol. Den gennemsnitlige bogbestand var 14 bøger. Vi viser her den originale bogliste, og vi har også rekonstrueret et sådant præstebibliotek: Hr. Jørgens i Øster Brønderslev sogn. Blandt hans 8 bøger var den tyske reformator Urban Rhegius' katekismus, Hans Tausens oversættelse til dansk af de fem Mosebøger, den tyske teolog Anthon Corvins Postille og Peder Palladius' katekismus. Bemærkelsesværdigt er det, at Hr. Jørgen, i lighed med nogle andre kolleger i stiftet, ikke ejede hele Bibelen.

$\mathrm{F}$ ra den sjællandske kirke Torslunde er bevaret den smukke og i kirkehistorisk henseende uhyre spændende alterbordsforside, udført i samtiden, 1561. På den her forstørrede kopi ser man, at maleren har villet vise kernen i den lutherske menighedsgudstjeneste, til forskel fra den katolske messe. Kun dåb og nadver er sakramenter. Dåben foretages ved overøsning. Her afveg man ganske vist fra Wittenbergs ordning, hvor man brugte fuld neddykning. Men det nægtede de at følge her i landet, for, som Peder Palladius sagde med henblik på de kolde kirker og vel uopvarmede vand - det er barnets frelse, ikke dets fordærv, vi søger i dåben. I nadveren modtager lægfolket nu også vinen. Præsten, som bærer en borgerlig dragt fra samtiden, peger hen på den korsfæstede, som, ganske svarende til Luthers teologi, udgør billedets centrum. Værd at bemærke er også, at man ved de kirkelige handlinger har bevaret brugen af de farvede liturgiske klæder. Dette var også i overensstemmelse med Luther, som forholdt sig ganske afslappet til disse minder om den katolske messe. Alterets hvide dug og to lys omtales i Palladius' Visitatsbog

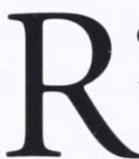
eformationskongen Christian d.3. var et alvorligt fromt menneske, en roende kristen, fast forankret i den lutherske tro. Hans dagligliv lå i religiøse rammer, andagter, bønner, salmer og prædikener. Ingen måtte forstyrre kongen om morgenen, før han højt for sig selv havde læst i Bibelen, ved taflet samtalede han gerne med hofprædikanter eller andre lærde mænd. Af og til prædikede han selv, og han var særdeles meget optaget af teologiske emner. Livet igennem brevvekslede han med teologerne i Wittenberg - Martin Luther, Philipp Melanchthon, Johann Bugenhagen, Georg Major, Justus Jonas og andre - som han beundrede umådeligt. Han sendte dem gaver som smør og sild - allerede dengang efterspurgte dansk eksportartikler! - og da det viste sig, at disse varer ved ankomsten til Wittenberg ikke helt levede op til kvalitetskravene, ændrede han det dertil, at berømthederne i Wittenberg i stedet for årligt modtog en pengegave af kongen, 50 daler, svarende til en fjerdedel af en københavnsk professors gage dengang. Kongen læste flittigt i de mange teologiske bøger, som man sendte til ham fra Wittenberg. Men han læste også kritisk, og da nogle af teologerne med tiden begyndte at afvige fra det, som kongen mente var den wittenbergske teologi, greb han straks ind og forsøgte at bringe dem tilbage på den rette vej. At de ikke uden videre kunne følge ham her, voldte ham både forbløffelse, sorg og vrede. 
Var sikker på, atjeg nok skal vare superintendenternes fader! Sådan sagde Christian d.3. en gang til Bugenhagen. Det var en træffende bemærkning. Den evangelisk-lutherske kirke i Danmark fik ved reformationen ikke en ærkebiskop. Kongen blev heller ikke en summus episcopus, men i praksis blev Christian d.3. og efterfølgerne kirkens ubestridte leder. Det gjaldt både økonomi, embedsbesættelser og lærespørgsmål.

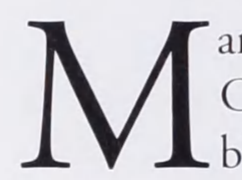

artin Luthers sidste brev til Christian d.3. - det vises her blev skrevet kun få uger før Luthers rejse til Eisleben, hvor han afgik ved døden den 18. februar 1546. Han sendte her kongen nyheder og berettede fornøjet om, hvorledes paven og kardinalerne i Rom havde holdt messer, middage og selskaber for at fejre, at den tyske katolske hertug Heinrich af Braunschweig nu havde udryddet lutherske kættere - som de urigtigt havde fået indtrykket af. Men det viste sig, at det tværtimod var lutherske fyrster, som havde besejret Heinrich, og det viste klart, skrev Luther, at Gud var fuldstændig ligeglad med alle de forbandede katolske messer. Luther takkede også kongen for alt det gode, han gjorde for

Wittenbergteologerne, og han tilføjede til sidst: selv vandrer jeg nu dagligt på gravens rand...

Christian d.3. svarede, at det slet ikke var nødvendigt at takke ham. Han ville gerne gøre meget mere for Wittenbergerne, hvis han blot vidste, hvordan han kunne glæde dem. De nyheder, som Luther havde sendt ham, bekræftede også ham deri, at den almægtige Gud tilintetgorde alle angreb fra de gudløse papister, og kongen udtrykte det håb, at Gud ville lade Luther leve længe endnu, den kristne kirke og den sande lære til hjælp og glæde.

Men da dette brev forlod det kgl. kancelli i København, var Luther allerede afgået ved døden. Da den sørgelige nyhed nåede København noterede en skriver - som det ses her i montren - i kancelliets kopibog, hvor de afsendte breve blev indskrevet: dette brev nåede den gode og fromme Luther ikke at lase i denne verden.

Noter

Denne artikel er en dansk udgave af min engelske forelæsning Luther and the Reformation in Denmark, som jeg holdt i Dronningesalen, Det Kgl. Bibliotek, den 6.august 2002, i anledning af præsentationen af udstillingen Luther og reformationen i Danmark for deltagerne i $10^{\text {th }}$ International Congress for Luther Research, Copenhagen 4.8.-9.8. 2002. Her gengives forelæsningsmanuskriptet, dvs. at det ikke er forsynet med fodnoter. Nogle generelle litteraturhenvisninger anføres til sidst. Forelæsningens detaljerede henvisninger til udstillingens montrer er udeladt.

\section{Litteratur}

Martin Schwarz Lausten: Reformationen i Danmark, 2. udg., Akademisk forlag, København 2002.

Christian d. 2. mellem paven og Luther. Tro og politik omkring "den rode konge" i eksilet og fangenskabet, Akademisk forlag, København 1995.

Kirkeordinansen 1537/39, Latin og dansk, Akademisk forlag, København 1989. Danmarks kirkehistorie, 2. udg. 6. opl. Gyldendals forlag, København 2000. 